\title{
Communication systems for scientific collaboration and mobility. Evidence from Spain
}

\author{
Pedro Aceituno-Aceituno; Andreu Casero-Ripollés; Joaquín Danvila-Del-Valle; \\ Carlos Bousoño-Calzón
}

Nota: Este artículo se puede leer en español en:

https://recyt.fecyt.es/index.php/EPI/article/view/73088

How to quote this article:

Aceituno-Aceituno, Pedro; Casero-Ripollés, Andreu; Danvila-Del-Valle, Joaquín; Bousoño-Calzón, Carlos (2019). "Communication systems for scientific collaboration and mobility. Evidence from Spain". El profesional de la información, v. 28, n. 6, e280617.

https://doi.org/10.3145/epi.2019.nov.17

Manuscript received on $20^{\text {th }}$ June 2019 Accepted on $13^{\text {th }}$ November 2019

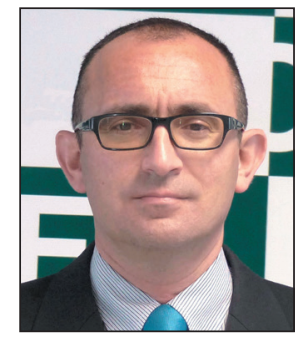

Pedro Aceituno-Aceituno $\square$ http://orcid.org/0000-0001-9034-8673

Universidad a Distancia de Madrid Departamento de Administración y Dirección de Empresas y Economía Carretera de La Coruña, Km. 38,500 28400 Collado Villalba (Madrid), Spain pedro.aceituno@udima.es

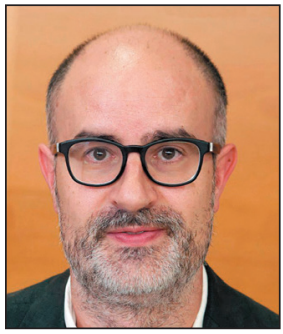
Andreu Casero-Ripollés http://orcid.org/0000-0001-6986-4163

Universitat Jaume I de Castelló Departamento de Ciencias de la Comunicación Avenida de Vicent Sos Baynat, $\mathrm{s} / \mathrm{n}$ 12071 Castelló de la Plana, Spain casero@uji.es

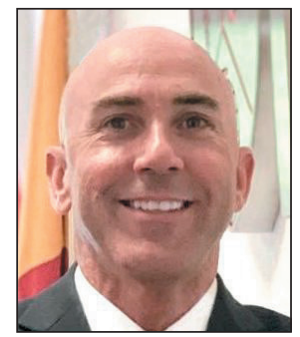
Joaquín Danvila-Del-Valle https://orcid.org/0000-0002-4675-3599
Universidad a Distancia de Madrid Departamento de Administración y Dirección de Empresas y Economía Carretera de La Coruña, Km. 38,500 28400 Collado Villalba (Madrid), Spain joaquin.danvila@udima.es

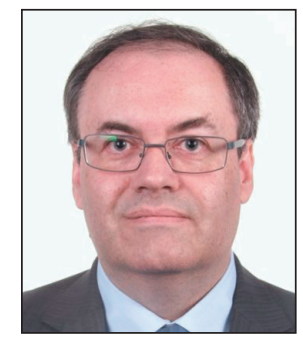

Carlos Bousoño-Calzón http://orcid.org/0000-0001-7065-5692

Universidad Carlos III de Madrid Comunicaciones Avenida de la Universidad, 30 28911 Leganés (Madrid), Spain cbousono@tsc.uc3m.es Departamento de Teoría de la Señal y

\begin{abstract}
Given the effectiveness shown for the creation of collaborative environments of social network sites and the scarcity of work on their use by researchers, the purpose of this article is the analysis of the use of communication systems in scientific collaboration by the collective most involved in scientific mobility. A survey among the Spanish groups most involved in scientific mobility $(n=415)$ was carried out to analyze the communication systems they use for their collaboration. Scientists use social network sites scarcely for their collaboration, although these can serve as a complement to face-to-face communication systems. The main framework for their collaboration is meetings, congresses, and workshops. Our results can contribute to articulate effective policies to improve this mobility for the benefit of the processes of creation and transfer of scientific knowledge of the countries of origin.
\end{abstract}

\section{Keywords}

Scientific mobility; Researchers; Scientifics; Scientific collaboration; Scientific career; Scientific communication; Scholarly communication; Social network sites; Scholarly social networks; Scientific congresses; Email; Spain.

\section{Acknowledgements}

To all the researchers, associations and institutions that have supported this work. The authors also thank Elisa Ambrogio and Laura Mesanza for her translation of this paper.

\section{Financing}

This study has been financed by Grupo Reacciona and Universitat Jaume I in Castellon (Plan Propio de Investigación 2017 with number UJI-B2017-55). 


\section{Introduction}

The mobility of researchers abroad is one of the main phenomena that currently affects the scientific system. Countries with greater economic power and better job opportunities attract a growing number of researchers (Gaillard; Gaillard, 2015; Appelt et al., 2015), as they contribute to creating knowledge with their publications (Kato; Ando, 2017; Sugimoto et al., 2017) and to carry out transfer activities (Gibson; McKenzie, 2014), especially through patent applications (Montobbio; Sterzi, 2013; Mihi-Ramírez; García-Rodríguez; Cuenca-García, 2016). This phenomenon increases the strategic importance of collaborative processes among scientists, understood as the interactions to produce or improve a result related to the generation of knowledge

The mobility of researchers abroad is one of the main phenomena that affects the scientific system

(publications or patents, for example). For these to be created, maintained and developed, communication systems are essential, also understood as those mechanisms used by research staff to establish contacts and communicate with each other. Its importance increases even more in the case of scientific mobility. Therefore, it is essential to know how to use communication systems to promote collaboration between researchers in the context of scientific mobility.

Although researchers may have other motivations (Baruffaldi; Landoni, 2016), they usually leave their country of origin at the beginning of their scientific career (Deville et al., 2014; Gargiulo; Carletti, 2014) in search of the so-called accumulated or differential advantages for young researchers, which are those that will allow them to stand out from those who do not have such advantages in the future. This concept, known as the Mateo Effect, was discovered by Merton (1968) and the advantages to which it refers are the training, financing, prestige of the host institution, work in high-excellence teams and research career (Merton, 1988), the latter being particularly important for its high value to increase the distances between researchers (García-Romero, 2012; Gargiulo; Carletti, 2014).

The country of origin loses this scientific talent, but mobility is important, because the people involved in it have more opportunities to increase their competitiveness (McEvily; Zaheer, 1999). To take advantage of the knowledge of their researchers (Fangmeng, 2016) and that of their networks abroad (Yazdizadeh et al., 2014; Kato; Ando, 2017), and be more competitive (Jacob; Meek, 2013; Rodrigues; Nimrichter; Cordero, 2016), countries of origin have to strengthen coIlaboration with their researchers abroad (Del-Río-Duque, 2009; Zdravkovic; Chiwona-Karltun; Zink, 2016; Palacios-Callender; Roberts, 2018), since there are cases that show that this is the way in which their scientific productivity is much higher (Akbaritabar; Casnici; Squazzoni, 2018) as well as their probability of returning (Baruffaldi; Landoni, 2012).

It is essential to know the use of communication systems that favor collaboration between researchers

Within these policies to encourage collaboration with researchers abroad, communication is a key aspect to promote scientific collaboration with researchers residing abroad. In some cases, such as the emergency campaigns of Non-Governmental Organisations for Development (NGDOs), communication through social network sites demonstrates its effectiveness in achieving collaborative environments (Arroyo-Almaraz; Calle-Mendoza; Van-Wyk, 2018). In the case of researchers, some authors have shown that a large number of them increasingly use Internet-based tools such as email for the coordination activities of the scientific team (Walsh et al., 2000). Similarly, Ward, Bejarano and Dudás (2015) have analyzed various academic platforms and social network sites used for the promotion of researchers' professional profiles. Barjak, Li and Thelwall (2007) and Mas-Bleda and Aguillo (2013) have studied the use of personal websites to disseminate results.

Bar-Ilan et al. (2012) also extend the study of this last type of use to social network sites, although Baruffaldi, Di-Maio and Landoni (2017) state that there is little research on how these networks are used and perceived by scientists.

With regard to these social network sites, Jurgenson (2012) points out that they can increase face-to-face or personal interactions. In the case of researchers, Murthy and Lewis (2015), through a study on these hybrid online / personal communities, have concluded that social network sites can serve as a complement to disseminate information, but are not used for scientific collaboration. Along the same lines, Campos-Freire and Rúas-Araújo (2016) demonstrate that the use of social network sites aimed at academics, such as ResearchGate or Academia.edu, is aimed at disseminating and following publications and achieving reputation and visibility (Rodríguez-Bravo; Nicholas, 2019), but not to establish contacts that could lead to future collaborations. Although social network sites allow low-cost contacts (Grabowicz et al., 2012), the search for collaboration is not one of the main uses given by scientists to generalist platforms such as Twitter (Segado-Boj; Chaparro-Domínguez; Castillo-Rodríguez, 2015). Likewise, González-Díaz, Iglesias-García and Codina (2015) demonstrate that the use of ResearchGate or Academia.edu in Spanish universities is insufficient or, in some cases, virtually non-existent. Despite their low frequency of use, Spanish researchers positively value the usefulness of these digital scientific social network sites (Rodríguez-Fernández; Sánchez-Amboage; Martínez-Fernández, 2018). In the case of Italy, Manca and Ranieri (2017) maintain that the use of these platforms increases with the age and years of experience of the researchers. On the other hand, Baruffaldi, Di-Maio and Landoni (2017) corroborate that international scientific mobility correlates with the size of the network of scientists, although it is not correlated with the probability of using social network sites. 
From the beginning of this decade to the present, several studies show that the mobility of Spanish scientists depends largely on job opportunities and scientific careers (Fernández, 2010; Aceituno-Aceituno et al., 2015a; 2017), so that the agents of the Sistema Español de Ciencia y Tecnología (Secti), who have decision-making capacity in these matters should establish policies in this regard. Furthermore, as regards the possibility of collaboration between Spanish science and Spanish scientists abroad, their level of collaboration with international institutions is quite high compared to their level of collaboration with national scientific institutions (Aceituno-Aceituno et al., 2015b). Given this low level of collaboration, the articulation of these scientific mobility policies in Spain may receive a significant boost from the activation of communication systems that increase such collaboration.

The aim of this paper is to analyze the use of communication systems for scientific collaboration by the groups of researchers most involved in scientific mobility. In this way, guidelines can be provided so that effective policies can be articulated to improve such mobility for the benefit of the processes of creation and transfer of scientific knowledge.

\section{Methodology}

To fulfil the purpose of this paper, a quantitative methodology was selected based on a descriptive study supported by data on the use of communication systems for scientific collaboration according to Lafuente and Marín-Egoscozábal (2008).

\subsection{Population and sample}

This research focuses on the Spanish groups most involved in scientific mobility, which include the following three:

1) Young researchers working in Spain (YRS), but who have not yet gone abroad, since they have a high probability of doing so to achieve differential advantages (Merton, 1968; 1988) and, above all, new opportunities to advance their scientific career (García-Romero, 2012; Gargiulo; Carletti, 2014). This group is made up of researchers who have started doctoral programmes in Spain and have continued to carry out scientific research up to the age of 41 . In addition to young researchers, the other two groups included are:

2) Spanish scientists who carry out their activity abroad (SSA), and

3) scientists who return to Spain after carrying out their scientific activity for at least one year abroad (SRS).

There are no updated figures available in relation to the population and the profile of the researchers in these groups. Only in the case of SSA have several attempts have been made to conduct a census in Spain. This monitoring of scientists abroad is a fairly complex issue for all countries of origin, as recognised by Baruffaldi and Landoni (2012). For this reason, there is no comprehensive census of this type in Spain. Attempts have been made but they have only produced partial results (R. E., 2003; Fernández-Magariño, 2005; Fernández, 2010; Delgado-Morales; Melchor; Oliver, 2013).

To overcome this drawback of the lack of exact figures on the population and the profile of the three groups, the procedure used by Baruffaldi and Landoni (2012), who had similar difficulties in accessing data from foreign researchers in Italy, has been followed. To this end, our questionnaire has been sent to scientists by the associations and institutions that support the proper development of research careers in Spain, as can be seen in Table 1 of the survey data sheet.

\subsection{Data-collection instruments and procedure}

The questionnaire for this paper has been approved by the Comité de Ética de la Universidad a Distancia de Madrid (Udima). In this survey, the variables have been grouped into the following three blocks:

\section{Block 1. Choice of communication systems for scientific collaboration}

In this block, based on what was stated by Murthy and Lewis (2015) regarding hybrid online / physical communities, as the first variable, scientists had to identify their choice of communication systems for scientific collaboration according to one of the four systems they have used the most:

a) Researchers who mainly use face-to-face communication systems for their scientific collaboration.

b) Researchers who mainly use social network sites for their scientific collaboration.

c) Researchers who use a balanced combination of face-to-face communication systems and social network sites for their scientific collaboration.

d) Researchers who do not collaborate.

The definitions of these options are as follows: 
Table 1. Survey datasheet

\begin{tabular}{|c|c|}
\hline Universe & 6,383 participants \\
\hline $\begin{array}{l}\text { Data-collection } \\
\text { technique }\end{array}$ & Online application of the questionnaire \\
\hline $\begin{array}{l}\text { Dates of fieldwork } \\
\text { and questionnaire } \\
\text { dissemination } \\
\text { procedure }\end{array}$ & $\begin{array}{l}\text { This work was carried out between } 14 \text { December } 2017 \text { and } 30 \text { April } 2018 \text {. During this period all these associations and } \\
\text { institutions disseminated the survey among their associated scientists by email. Every two weeks, the authors of this pa- } \\
\text { per informed the associations and institutions of the number of responses obtained so that they could continue making } \\
\text { calls to increase the number of responses. In the third week of April } 2018 \text {, the last call was made to answer the survey and } \\
\text { thereafter there was practically no increase in the number of responses. Therefore, the questionnaire was concluded on } \\
30 \text { April } 2018 \text {. }\end{array}$ \\
\hline Sample size & 415 (YRS: 200; SSA: 147; SRS: 68). \\
\hline Confidence level & $95 \%$ \\
\hline $\begin{array}{l}\text { Maximum accepted } \\
\text { sampling error }\end{array}$ & $\pm 4.70 \%$ : this error falls within the parameters required in a sampling of these characteristics (Kalton, 1983). \\
\hline $\begin{array}{l}\text { Institutions co- } \\
\text { Ilaborating in the } \\
\text { dissemination of the } \\
\text { survey }\end{array}$ & $\begin{array}{l}\text { YRS: } \\
\text { Federación de Jóvenes Investigadores (FJI), Fundación Universidad-Empresa (FUE), Colegio Oficial de Físicos (Cofis), Federación } \\
\text { Española de Biotecnólogos (FEBiotec), Aratech - lifestyle technology and Centro de Innovación de la Universidad de Oviedo. } \\
\text { SSA: } \\
\text { Society of Spanish Researchers in the United Kingdom / Comunidad de Científicos Españoles en el Reino Unido (SRUK / CERU), } \\
\text { Científicos Españoles en la República Federal de Alemania (Cerfa), Asociación de Científicos Españoles en Japón / Association } \\
\text { of Spanish based in Japan (ACE Japón), Españoles Científicos en Estados Unidos (ECusa), Asociación de Científicos Españoles en } \\
\text { Suecia / Association of Spanish Scientists in Sweden (ACES / FSFS), Spanish Research in Australia-Pacific / Investigadores Espa- } \\
\text { ñoles en Australia-Pacífico (SRAP / IEAP), Científicos Españoles en Dinamarca / Spanske Forskere i Danmark (CED), Asociación } \\
\text { de Investigadores Españoles en la República Italiana (Asieri), Red de Científicos Españoles en México (Recemex), Asociación de } \\
\text { Investigadores Españoles en Irlanda / Spanish Research Society of Ireland (SRSI), Asociación de Científicos Españoles en Suiza } \\
\text { (Acech), Científicos Españoles en Bélgica / Spanish Scientists in Belgium (CEBE), Sociedad de Investigadores Españoles en Fran- } \\
\text { cia / Société de Chercheurs Espagnols en France (SIEF-SCEF) and Red de Investigadores China-España (RICE). } \\
\text { SRS: } \\
\text { Científicos Retornados a España (CRE) and Fundación Universidad (FUE). }\end{array}$ \\
\hline
\end{tabular}

- Researchers who mainly use face-to-face communication systems for their scientific collaboration: These are scientists who essentially carry out their scientific collaboration activities in person and also through communication media other than social network sites (telephone, email, videoconferencing, for example). Their use of social network sites is quite limited (involving less than about $20 \%$ of their scientific collaboration activities).

- Researchers who mainly use social network sites for their scientific collaboration: These are scientists who communicate through social network sites for their scientific collaboration activities and also through communication media other than social network sites (telephone, email, videoconferencing, for example). Physical presence and face-to-face communication for scientific collaboration activities is quite low (accounting for less than about $20 \%$ of their scientific collaboration activities).

- Researchers who use a balanced combination of face-to-face communication systems and social network sites for their scientific collaboration: Scientists who carry out their scientific collaboration activities by combining both systems (approximately 50\% each). These researchers interchangeably use communication systems other than social network sites such as telephone, email, or videoconferencing, for example.

- Researchers who do not collaborate: These researchers carry out their scientific work on their own and their collaboration with other researchers is very limited or non-existent.

\section{Block 2. Media used by researchers who mainly use face-to-face communication systems for scientific collaboration}

Only scientists who have been identified in the previous section as users of this communication system have answered to what extent they use the defined communication systems to collaborate scientifically. The selection of these was not deliberately exhaustive to obtain as many responses as possible, so only the most common and generally used have been identified both in this communication system and in others. Similarly, it is specified that for the three communication systems certain ways of communication via telephone, Internet and mixed telephone-Internet have been identified. Taking all this into consideration, the following variables and their related ways of communication have been considered:

- face-to-face communication based on physical presence (face-to-face meetings and congresses / seminars),

- telephone-based communication (telephone),

- Internet-based communication (email, websites of scientific institutions and personal websites) and

- mixed telephone-Internet communication systems (videoconferencing via Skype and videoconferencing via Google Hangout).

\section{Block 3. Media used by researchers who mainly use social network sites for their scientific collaboration}

Data on these variables have been collected only for researchers who use this systematic for their scientific collaboration. The same variables established for the previous case have been adapted for this type of communication system 
related to social network sites by changing the ways of communication based on physical presence for those based on the aforementioned social network sites. These variables and their related ways of communication are the following:

- communication based on both generalist and scientific social network sites (Facebook, Twitter, ResearchGate, Academia.edu, Epernicus Network and blogs),

- telephone-based communication (telephone),

- Internet-based communication (e-mail, websites of scientific institutions and personal websites) and

- mixed telephone-Internet ways of communication (videoconferencing via Skype and videoconferencing via Google Hangout).

Block 4. Media used by researchers who use a balanced combination of face-to-face communication systems and social network sites for their scientific collaboration

Finally, data have been collected from scientists who use this system in their scientific collaboration, adapting the above variables to take into account both ways based on physical presence and those based on social network sites. The variables and the related ways of communication considered are those shown below:

- face-to-face communication based on physical presence (face-to-face meetings and congresses / seminars),

- communication based on both generalist and scientific social network sites (Facebook, Twitter, ResearchGate, Academia.edu, Epernicus Network and blogs),

- telephone-based communication (telephone),

- Internet-based communication (email, websites of scientific institutions and personal websites) and

- mixed telephone-Internet ways of communication (videoconferencing via Skype and videoconferencing via Google Hangout).

In the assessment of the ways of communication associated with each of these variables, a Likert type scale of 1 to 10 points has been used, where the higher values mean a greater degree of use of the medium for scientific collaboration and the lower values a lower degree of use. As will be seen later in the results, only the percentages that are among the higher values from "highly used" (6) to "very highly used" (10) have been taken into account.

\author{
$23 \%$ of young researchers think they will \\ go abroad and $45.5 \%$ will do so depen- \\ ding on job opportunities
}

As a complement to the assessment of these variables, a profile of the participants has been produced to provide guidelines for effective policies to be articulated to improve scientific mobility. In this respect, we followed the study by Franzoni, Scellato and Stephan (2012), in which the determining factors in the mobility of leading scientists from the 16 countries with the greatest scientific production were reviewed. In this paper, which in the case of Spain shows that four out of ten scientists claim that their return depends on job opportunities, a single question was asked about the probability of scientists returning to their countries of origin in the future, with four possible responses: yes, no, depends on the job opportunities and, perhaps part-time or at the end of my career.

In our survey, SSA were asked the same question. SRS and YRS were also asked, although in these cases about the probability of going abroad. To complete this profile, we have followed the paper by Baruffaldi and Landoni (2012), which also examines the probability of return of scientists and concludes that this probability increases with a less permanent professional situation and for mobility reasons not related to the improvement of job. Therefore, according to this study, a variable related to the position held within the scientific career has been included.

\section{Results}

\subsection{Profile of the groups of researchers involved in scientific mobility}

Regarding the profile of YRS, 19.50\% (39/200) are sure they will not go abroad to continue their research. This percentage is lower than both the $23.00 \%$ (46/200) who say they are definitely going abroad and to the $45.50 \%$ (91/200) who say they are likely to leave the country depending on job opportunities (see Figure 1.a.). Similarly, Figure 1.b. shows that the most of this group consists of predoctoral researchers in the public sector $(41.00 \%, 82 / 200)$, with a significant gap with respect to the other majority group composed of postdoctoral researchers in the public sector $(29.50 \%, 59 / 200)$. The sum of these temporary positions $(70.50 \%, 141 / 200)$ is much greater than that of permanent positions, such as those of tenured researchers, contracted doctoral researchers, public sector staff scientists and private sector team leader researchers, which only account for

Almost $10 \%$ of Spanish scientists who carry out their activity abroad are sure not to return to Spain $7.50 \%$ (15/200).

As can be seen in Figure 2.a., only 9.52\% (14/147) of the SSA group are sure that they will not return to Spain to carry out research, while the percentage of those who are sure that they will return $(11.56 \%, 17 / 147)$ is somewhat higher, and surprisingly, the percentage of those who might return to Spain depending on job opportunities is very high (67.35\%, 99/147). Regarding the position in the research career, the largest group of SSA is that of postdoctoral public sector 


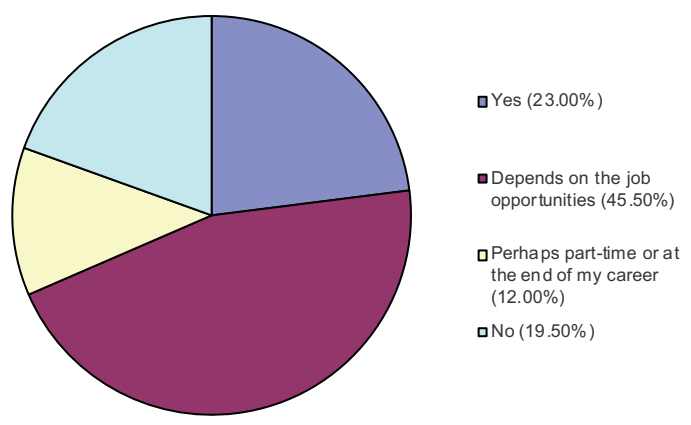

a) Scientific mobility trend

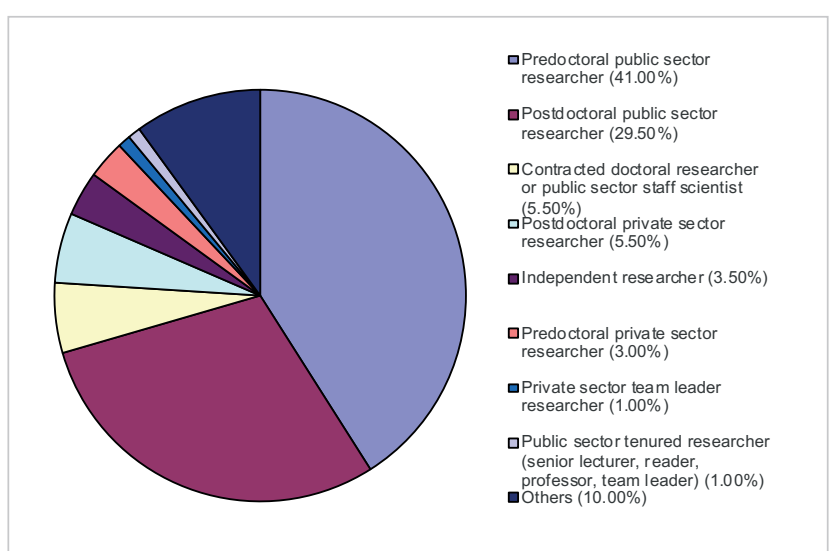

b) Position in scientific career

Figure 1. Profile of young researchers working in Spain (YRS)

researchers (32.65\%, 48/147, Figure 2.b.), which stands out from the next group composed of predoctoral researchers from the same sector with $21.09 \%(31 / 147)$. As in the above case, although with a narrower gap, the sum of these temporary positions with a higher percentage $(53.74 \%, 79 / 147)$ is considerably higher than that of permanent positions composed of tenured researchers and contracted doctoral researchers or public sector staff scientists, which only accounts for $26.53 \%$ (39/147).

Figure 3.a. shows that $14.71 \%(10 / 68)$ of the SRS will not return abroad to conduct research. On the other hand, the percentages of scientists in this group who are sure that they will go abroad again $(29.41 \%, 20 / 68)$ or who will leave depending on job opportunities $(38.24 \%, 26 / 68)$ are much higher. According to Figure 3.b., there are very few SRS that carry out their work in permanent positions in the scientific career. The sum of these positions accounts for a percentage of $25 \%(17 / 68)$, once they are added to the figures for contracted researchers, doctoral or scientific staff from the public sector $(17.65 \%, 12 / 68)$ and tenured researchers $(7.35 \%, 5 / 68)$.

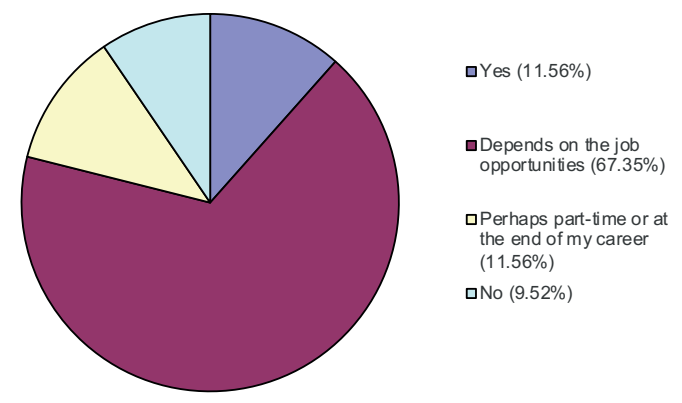

a) Scientific mobility trend

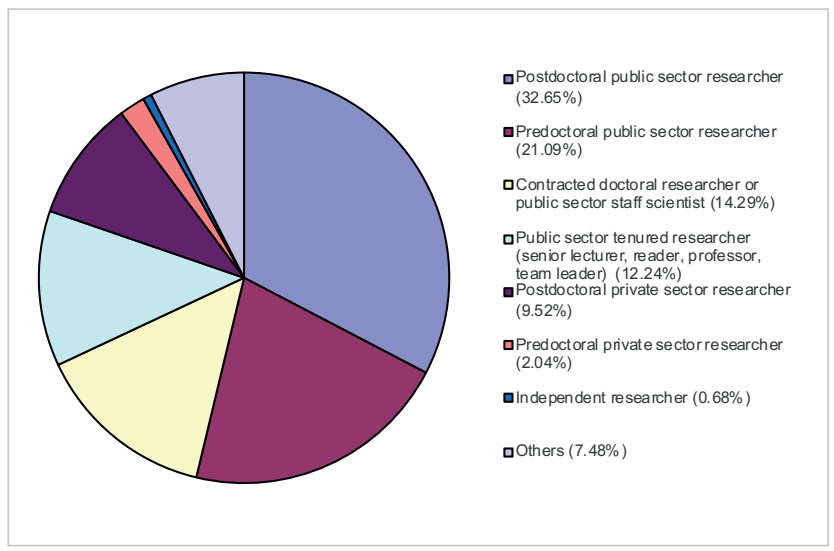

b) Position in scientific career

Figure 2. Profile of Spanish scientists who carry out their activity abroad (SSA)

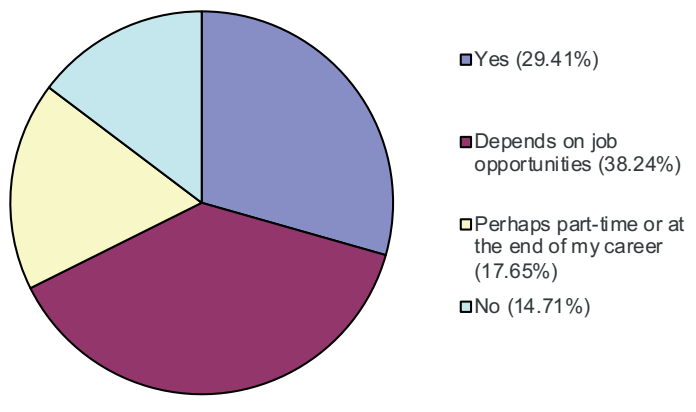

a) Scientific mobility trend

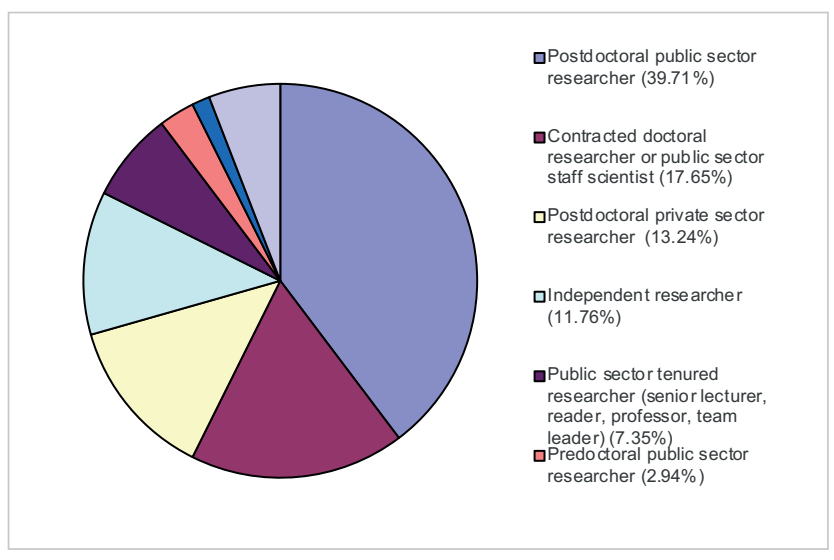

b) Position in scientific career

Figure 3. Profile of scientists who return to Spain after carrying out their scientific activity (SRS) 


\subsection{Communication systems used for collaboration in the context of scientific mobility}

Once the profile of the participants in the study is presented, the results regarding the communication systems used for the scientific collaboration of the groups studied are shown below. As can be seen in Table 2, there are very few YRS that do not form collaborations in the scientific field $(10 \%, 20 / 200)$. Based on this figure, those who collaborate using mainly face-to-face communication systems constitute the majority of this group with $47.50 \%$ (95/200), followed by those who use a balanced combination of face-to-face communication systems and social network sites with $37.50 \%(75 / 200)$, and finally, with a much lower percentage than the previous two groups, are the YRS who mainly use social network sites for scientific collaboration $(5 \%, 10 / 200)$.

Table 2. Classification of researchers according to the communication systems used for their scientific collaboration

\begin{tabular}{|l|c|c|}
\hline \multicolumn{1}{|c|}{ Choice of communication systems for scientific collaboration } & \multicolumn{2}{c|}{ Researcher group } \\
\cline { 2 - 3 } & $\begin{array}{c}\text { YRS } \\
\text { (N=200) }\end{array}$ & $\begin{array}{c}\text { SRS } \\
\text { (N=147) }\end{array}$ \\
\hline $\begin{array}{l}\text { a) \% Researchers who mainly use face-to-face communication systems for } \\
\text { their scientific collaboration }\end{array}$ & 47.50 & 51.02 \\
\hline $\begin{array}{l}\text { b) \% Researchers who mainly use social network sites for their scientific } \\
\text { collaboration }\end{array}$ & 5.00 & 1.36 \\
\hline $\begin{array}{l}\text { c) \% Researchers who use a balanced combination of face-to-face commu- } \\
\text { nication systems and social network sites for their scientific collaboration }\end{array}$ & 37.50 & 5.88 \\
\hline d) \% Researchers who do not collaborate & 10.00 & 43.54 \\
\hline
\end{tabular}

As regards the SSA, the percentage that does not collaborate $(4.08 \%, 6 / 147)$ is even lower than that of the YRS described above $(10 \%, 20 / 147)$. Among SSA, the majority group are those that mainly use face-to-face communication systems for scientific collaboration with $51.02 \%(75 / 147$, Table 2$)$. This group is followed by SSA that use a balanced combination of face-to-face communication systems and social network sites, with $43.54 \%$ (64/147), and well below that, the SSA that mainly use social network sites for scientific collaboration (1.36\%, 2/147). As in the case of YRS, the positions of the different groups are the same, but with higher percentages of researchers in the SSA group that use face-to-face communication systems for scientific collaboration and those that use a balanced combination of face-to-face communication systems and social network sites.

As for the SRS, the percentage that does not collaborate is also quite low, although somewhat higher than that of the SSA $(4.41 \%, 3 / 68)$. In the other SRS groups, there is a change in positions with respect to the previous groups, since those SRS that use a balanced combination of face-to-face communication systems and social network sites $(50.00 \%, 34 / 68)$ account for a higher percentage than those that mainly use face-to-face communication systems for scientific collaboration, with $39.71 \%(27 / 68)$. Finally, also within the SRS, the research staff who mainly use social network sites for their scientific collaboration is again a fairly small group, although with a higher percentage than that of the previous two groups $(5.88 \%, 4 / 68)$.

Specifically, within the face-to-face ways of communication, both meetings and congresses / seminars are the most commonly used by the vast majority of research staff that use this face-to-face communication system in the groups, with percentages of more than $80 \%$ in all of them (Table 3). To a considerably lesser extent, the use of telephone shows percentages exceeding $50 \%$ in research staff, who use this means of communication to a greater extent in the case of YRS

Table 3. Systems used by researchers who mainly use face-to-face communication systems for scientific collaboration

\begin{tabular}{|c|c|c|c|}
\hline \multirow[b]{2}{*}{ Communication systems } & \multicolumn{3}{|c|}{ Researcher group } \\
\hline & $\begin{array}{c}\text { YRS } \\
(\mathrm{N}=95)\end{array}$ & $\begin{array}{c}\text { SSA } \\
(\mathrm{N}=75)\end{array}$ & $\begin{array}{c}\text { SRS } \\
(\mathrm{N}=27)\end{array}$ \\
\hline \multicolumn{4}{|c|}{$\%$ Face-to-face communication based on physical presence } \\
\hline Face-to-face meetings & 92.63 & 90.67 & 92.59 \\
\hline Face-to-face congresses / seminars & 92.63 & 81.33 & 88.89 \\
\hline \multicolumn{4}{|l|}{ \% Telephone-based communication } \\
\hline Telephone & 56.84 & 44.00 & 51.85 \\
\hline \multicolumn{4}{|l|}{$\%$ Internet-based communication } \\
\hline Email & 89.47 & 96.00 & 96.30 \\
\hline Websites of scientific institutions & 46.32 & 52.00 & 37.04 \\
\hline Personal websites & 23.16 & 34.67 & 14.81 \\
\hline \multicolumn{4}{|c|}{$\%$ Mixed telephone-Internet means of communication } \\
\hline Skype videoconferencing & 35.79 & 70.67 & 51.85 \\
\hline Google Hangout videoconferencing & 4.21 & 20.00 & 11.11 \\
\hline
\end{tabular}


(56.84\%, 54/95) and SRS (51.85\%, 14/27), and a lesser extent in the case of SSA (44.00\%, 33/75). As far as Internet-based communication is concerned, email shows the highest percentages of use, with figures that are even higher than those of face-to-face communication, except in the case of YRS $(89.47 \%, 85 / 95)$. The other two options, such as the websites of scientific institutions and personal websites, are considerably less used, especially the latter, with percentages that do not exceed $35 \%$ in any of the groups. As for mixed telephone and Internet means of communication, Skype videoconferencing stands out in percentage of use compared to Google Hangout, especially in the cases of SSA $(70.67 \%, 53 / 75)$ and SRS $(51.85 \%, 14 / 27)$.

With regard to position by media, the most commonly used by all the groups in this communication system are email and the most specifically face-to-face media such as meetings and congresses / seminars (Table 3). By group, the YRS are those that use the two face-to-face media, in-person and telephone. The SSA occupy the first position in terms of the use of Skype videoconferencing, the websites of scientific institutions, personal websites and Google Hangout videoconferencing. The SRS only occupy the first position in percentage of use in the case of email.

As already said, researchers who mainly use social network sites for scientific collaboration represent only a small percentage. Table 4 shows the results of their use of different media and communication systems. It should be noted that, in general, although the percentages are high, the number of cases is low. Therefore, the YRS show a high use of ResearchGate (70\%, 7/10), as do the SRS (ResearchGate, 75\%, 3/4). The latter also show a high use of Academia.edu (75\%, 3/4). The use of the telephone by the YRS shows similar figures $(70 \%, 7 / 10)$. With regard to Internet-based communication, email again shows the highest percentages of use in this communication system, since it includes all the SSA and the SRS, and $90 \%(9 / 10)$ of the YRS. Within this group of communication systems, both the websites of scientific institutions and personal websites are considerably less used than the previous ones, especially the latter ( $25 \%$ in the case of the $\mathrm{SRS}$ ). Likewise, as in the face-to-face communication system, in the mixed telephone-Internet means of communication, Skype videoconferencing stands out in percentage of use compared to Google Hangout, especially in the case of the SSA $(100 \%, 2 / 2)$ and the YRS (70\%, 7/10).

Table 4. Systems used by researchers who mainly use social network sites for their scientific collaboration

\begin{tabular}{|c|c|c|c|}
\hline \multirow{2}{*}{ Communication systems } & \multicolumn{3}{|c|}{ Researcher group } \\
\hline & $\begin{array}{c}\text { YRS } \\
(N=10)\end{array}$ & $\begin{array}{c}\text { SSA } \\
(\mathrm{N}=2)\end{array}$ & $\begin{array}{c}\text { SRS } \\
(\mathrm{N}=4)\end{array}$ \\
\hline \multicolumn{4}{|c|}{$\%$ Communication based on social network sites } \\
\hline Facebook & 20.00 & 50.00 & 25.00 \\
\hline Twitter & 20.00 & 0.00 & 0.00 \\
\hline ResearchGate & 70.00 & 0.00 & 75.00 \\
\hline Academia.edu & 20.00 & 50.00 & 75.00 \\
\hline Epernicus Network & 0.00 & 0.00 & 25.00 \\
\hline Blogs & 0.00 & 0.00 & 25.00 \\
\hline \multicolumn{4}{|l|}{$\%$ Telephone-based communication } \\
\hline Telephone & 70.00 & 50.00 & 50.00 \\
\hline \multicolumn{4}{|l|}{$\%$ Internet-based communication } \\
\hline Email & 90.00 & 100 & 100 \\
\hline Websites of scientific institutions & 70.00 & 0.00 & 100 \\
\hline Personal websites & 10.00 & 0.00 & 25.00 \\
\hline \multicolumn{4}{|c|}{$\%$ Mixed telephone-Internet means of communication } \\
\hline Skype videoconferencing & 70.00 & 100 & 25.00 \\
\hline Google Hangout videoconferencing & 30.00 & 0.00 & 0.00 \\
\hline
\end{tabular}

With regard to the position of communication systems aimed at scientific collaboration (Table 4), the most commonly used by all groups in this system is email, followed at a considerable distance by Skype videoconferencing. These media are followed by the telephone and the websites of scientific institutions, which even exceed the most widely used social network sites such as ResearchGate and Academia.edu. The first positions by group are occupied by the YRS in the case of the telephone, Google Hangout videoconferencing and Twitter. In the case of the SSA this first position is occupied by email, Skype videoconferencing and Facebook. The SRS coincide with the SSA in the high use of email and occupy this position alone on the websites of scientific institutions, personal websites, ResearchGate, Academia.edu, Epernicus Network and blogs, being the group with highest percentage of use in social network sites within this communication system.

According to the data in Table 5, for the vast majority of researchers who use this combined face-to-face and social network system, face-to-face systems are the most commonly used in the three groups, only one case showing a percentage of lower than $80 \%$ (the SSA in face-to-face congresses / seminars with $79.69 \%, 51 / 64$ ). Among the media rela- 
ted to social network sites, ResearchGate is the most commonly used medium, with percentages exceeding $60 \%$ in the three groups, followed at a great distance by the second, which is Twitter, with percentages of use not exceeding $30 \%$ in any of the three groups. The telephone shows usage percentages exceeding $50 \%$ in all three groups, being higher than those of nearly all social network sites, with the exception of ResearchGate. Once again, email is the system with the highest percentages of use, with $100 \%$ of the SSA (64/64) and the SRS (34/34) and 93\% (70/75) of the YRS. Within these Internet-based systems, the websites of scientific institutions also show significant percentages of use with figures exceeding $60 \%$ in all three groups. Finally, personal websites show lower usage percentages, standing at $41.33 \%$ in the YRS (31/75) and $44.12 \%$ in the SRS (15/34). On the contrary, in the SSA these percentages are as low as $32.81 \%(21 / 64)$. For mixed telephone-Internet means of communication, the most surprising results are the high percentages of use of Skype videoconferencing, with values approaching $80 \%$ for the SSA $(76.56 \%, 49 / 64)$ and the SRS $(79.41 \%, 27 / 41)$, and the somewhat lower figure of 56\% (42/75) for the YRS, and the low values of Google Hangout videoconferencing, with percentages of around $20 \%$ in all three groups.

Table 5. Systems used by researchers using a balanced combination of face-to-face communication systems and social network sites for their scientific collaboration

\begin{tabular}{|c|c|c|c|}
\hline \multirow[b]{2}{*}{ Communication systems } & \multicolumn{3}{|c|}{ Researcher group } \\
\hline & $\begin{array}{c}\text { YRS } \\
(\mathrm{N}=75)\end{array}$ & $\begin{array}{c}\text { SSA } \\
(N=64)\end{array}$ & $\begin{array}{c}\text { SRS } \\
(N=34)\end{array}$ \\
\hline \multicolumn{4}{|l|}{$\%$ Communication based on physical presence } \\
\hline Face-to-face meetings & 89.33 & 95.31 & 88.23 \\
\hline Face-to-face congresses / seminars & 84.00 & 79.69 & 97.06 \\
\hline \multicolumn{4}{|c|}{$\%$ Communication based on social network sites } \\
\hline Facebook & 28.00 & 21.87 & 8.82 \\
\hline Twitter & 29.33 & 25.00 & 26.47 \\
\hline ResearchGate & 60.00 & 60.94 & 67.65 \\
\hline Academia.edu & 10.67 & 26.56 & 14.70 \\
\hline Epernicus Network & 2.67 & 1.56 & 5.88 \\
\hline Blogs & 16.00 & 15.62 & 14.70 \\
\hline \multicolumn{4}{|l|}{ \% Telephone-based communication } \\
\hline Telephone & 58.67 & 53.12 & 55.88 \\
\hline \multicolumn{4}{|l|}{$\%$ Internet-based communication } \\
\hline Email & 93.00 & 100 & 100 \\
\hline Websites of scientific institutions & 64.00 & 70.31 & 67.65 \\
\hline Personal websites & 41.33 & 32.81 & 44.12 \\
\hline \multicolumn{4}{|c|}{$\%$ Mixed telephone-Internet means of communication } \\
\hline Skype videoconferencing & 56.00 & 76.56 & 79.41 \\
\hline Google Hangout videoconferencing & 20.00 & 21.87 & 20.59 \\
\hline
\end{tabular}

With regard to position by media, the most commonly used by all the groups in this communication system are again email and face-to-face systems, but significant percentages are also obtained in Skype videoconferencing, the websites of scientific institutions and the social network ResearchGate. By group, the YRS occupy the first position in the use of the telephone, Facebook, Twitter and blogs. The SSA are the ones that most often use face-to-face meetings, email (with the same value as the SRS), the websites of scientific institutions, Google Hangout videoconferencing and Academia. $e d u$. Finally, the SRS are the ones that make the most use of face-to-face congresses / seminars, email, personal websites, Skype videoconferencing, ResearchGate and Epernicus Network.

\section{Discussion}

The main new contribution made by this research is the identification of face-to-face meetings, congresses and seminars as the most important mechanisms for collaboration in the context of scientific mobility. Despite the extension of digital communication systems, especially social network sites, events that bring the scientific community in person are the most commonly used means of establish or develop academic collaborations. This reaffirms the importance of face-to-face communication systems for creating collaborative dynamics in the scientific field.

The results obtained show that the researchers in the three groups studied (YRS, SSA and SRS) make little use of social network sites for their scientific collaboration. This finding is consistent with previous research (Baruffaldi; Di-Maio; Landoni, 2017; Campos-Freire; Rúas-Araújo, 2016; Segado-Boj; Chaparro-Domínguez; Castillo-Rodríguez, 2015). These digital platforms are designed to complement (Murthy; Lewis, 2015) face-to-face communication systems, such as congresses or meetings, and Internet-based communication tools, such as email. The YRS and the SSA mainly use a 
communication system dominated by face-to-face systems. On the other hand, the SRS use a combination of face-to-face systems and social network sites in their scientific collaboration. None of these three groups exceeds a percentage of use of the system focused mainly on social network sites of $6 \%$. These data show that the low use of these digital platforms in Spain detected by previous studies has not increased significantly (González-Díaz; Iglesias-García; Codina, 2015; Rodríguez-Fernández; Sánchez-Amboage; Martínez-Fernández, 2018). Despite its limited use, it is observed that, when they do use social network sites, the YRS prefer ResearchGate, the SSA opt for Facebook and Academia.edu and the SRS for ResearchGate and Academia.edu. The last group shows the highest percentage of use of social network sites.

Furthermore, according to the results obtained, the percentage of the YRS with a permanent position is quite low and a significant percentage of them would leave Spain to continue doing research depending on job opportunities. The proportion of the SSA with a permanent position is also quite low and the percentage of scientists from this group who would return to Spain depending on job opportunities is very high. As for the SRS, there are also few who have a permanent position and a significant percentage would return abroad depending on job opportunities. Given this profile for these three groups, and in accordance with what has been stated previously by Franzoni, Scellato and Stephan (2012) and also by Baruffaldi and Landoni (2012), the main axis of scientific mobility is the creation of job opportunities. If this does not happen, knowledge of Spanish scientific mobility (Fangmeng, 2016) and that of its networks abroad (Yazdizadeh et al., 2014; Kato; Ando, 2017) may be wasted, but the results of this paper do show that these researchers are mostly collaborators, and for this purpose they rely on communication systems, so to strengthen collaboration using these systems (Del-Río-Duque, 2009; Zdravkovic; Chiwona-Karltun; Zink, 2016; Palacios-Callender; Roberts, 2018), it is necessary to know the degree of their use, as shown in this paper, as this will improve competitiveness (Jacob; Meek, 2013; Rodrigues; Nimrichter; Cordero, 2016), scientific productivity (Akbaritabar; Casnici; Squazzoni, 2018) and the ability to attract scientific talent (Baruffaldi; Landoni, 2012) to the Sistema Español de Ciencia y Tecnología (Secti).

\section{Conclusions}

The results obtained have allow us to identify the main parameters for the use of communication systems in collaboration processes linked to scientific mobility in the case of Spain. This allows us to draw several conclusions aimed at activating and articulating scientific policies to improve the creation and transfer of scientific knowledge within this framework.

In order to promote these policies, taking into account these results and the fact that the vast majority of scientists involved in mobility collaborate, we recommend organizing face-to-face events in the form of congresses from platforms such as the Red de Asociaciones de Investigadores y Cientificos Españoles en el Exterior (Raicex) and its associations, which rely on emails from Spanish researchers abroad. These meetings, preferably focused on specific topics or scientific disciplines, could result in the necessary face-to-face meetings for scientists working at the Sistema Español de Ciencia y Tecnología (Secti), and groups involved in scientific mobility to get in touch and establish procedures to carry out such collaboration. In these events, whose organization and results can also be disseminated in a complementary way by the different social network sites, more general aspects could be presented such as career plans both to continue conducting research abroad and to return to Spain, foreign and domestic job opportunities, research projects, scientific results, scientific information, and possible collaborations to produce publications or actions for the transfer of scientific knowledge.

All these aspects can contribute to making scientific mobility increase the possibilities of improvement in the research career and in the creation of job opportunities. In this regard, some studies show that scientific mobility promotes not only entrepreneurship, but also intra-entrepreneurship within organizations (Aceituno-Aceituno et al., 2018), which can be an important value when it comes to obtaining a job opportunity within the Secti, as Spanish scientific and business organizations can take advantage of the skills developed abroad, or the greater access to financial resources of Spanish researchers abroad by hiring them. In this way, both the Young researchers working in Spain (YRS) that wish to move abroad and the scientific and business organizations that wish to broaden their horizons abroad can cooperate and be helped by the Spanish scientists who carry out their activity abroad (SSA) and the Scientists who return to Spain after carrying out their scientific activity (SRS), through the most widely used communication systems, as they have greater collaboration networks abroad and accumulate greater experience in this regard.

\section{References}

Aceituno-Aceituno, Pedro; Danvila-Del-Valle, Joaquín; González-García, Abel; Bousoño-Calzón, Carlos (2018). “Entrepreneurship, intrapreneurship and scientific mobility: The Spanish case". PLoS one, v. 13, n. 9. https://doi.org/10.1371/journal.pone.0201893

Aceituno-Aceituno, Pedro; Melchor, Lorenzo; Danvila-Del-Valle, Joaquín; Bousoño-Calzón, Carlos (2017). “Cumulative advantages and social capabilities in scientific mobility in the health sciences: The Spanish case". PLoS one, v. 12, n. 3. https://doi.org/10.1371/journal.pone.0173204

Aceituno-Aceituno, Pedro; Romero-Martínez, Sonia-Janeth; Víctor-Ponce, Patricia; García-Núñez, José (2015a). “Factores determinantes de la movilidad de investigadores españoles en Ciencias de la Salud". Medicina clínica, v. 144, n. 11, pp. 520-524.

https://doi.org/10.1016/j.medcli.2014.10.020 
Aceituno-Aceituno, Pedro; Romero-Martínez, Sonia-Janeth; Víctor-Ponce, Patricia; García-Núñez, José (2015b). “An analysis of national collaboration with Spanish researchers abroad in the health sciences". Health research policy and systems, v. 13, art. 67.

https://doi.org/10.1186/s12961-015-0055-2

Akbaritabar, Aliakbar; Casnici, Niccolò; Squazzoni, Flaminio (2018). "The conundrum of research productivity: A study on sociologists in Italy". Scientometrics, v. 114, n. 3, pp. 859-882.

https://doi.org/10.1007/s11192-017-2606-5

Appelt, Silvia; Van-Beuzekom, Brigitte; Galindo-Rueda, Fernando; De-Pinho, Roberto (2015). Which factors influence the international mobility of research scientists?. Paris: Organisation for Economic Co-operation and Development (OECD).

https://doi.org/10.1787/5js1tmrr2233-en

Arroyo-Almaraz, Isidoro; Calle-Mendoza, Samuel; Van-Wyk, Cliff (2018). "La eficacia en la comunicación de las ONGD. El uso de Facebook en campañas de emergencia”. Revista latina de comunicación social, n. 73, pp. 765-789.

http://www.revistalatinacs.org/073paper/1281/40es.html

Bar-Ilan, Judit; Haustein, Stefanie; Peters, Isabella; Priem, Jason; Shema, Hadas; Terliesner, Jens (2012). “Beyond citations: scholars' visibility on the social web". En: Proceedings of $17^{\text {th }}$ Int l conf on science and technology indicators, pp. 98-109.

https://arxiv.org/abs/1205.5611

Barjak, Franz; Li, Xuemei; Thelwall, Mike (2007). “Which factors explain the web impact of scientists' personal homepages?". Journal of the Association for Information Science and Technology, v. 58, n. 2, pp. 200-211.

https://doi.org/10.1002/asi.20476

Baruffaldi, Stefano H.; Di-Maio, Giorgio; Landoni, Paolo (2017). “Determinants of PhD holders' use of social networking sites: An analysis based on LinkedIn". Research policy, v. 46, n. 4, pp. 740-750.

https://doi.org/10.1016/j.respol.2017.01.014

Baruffaldi, Stefano H.; Landoni, Paolo (2012). "Return mobility and scientific productivity of researchers working abroad: The role of home country linkages". Research policy, v. 41, n. 9, pp. 1655-1663.

https://doi.org/10.1016/j.respol.2012.04.005

Baruffaldi, Stefano H.; Landoni, Paolo (2016). “Mobility intentions of foreign researchers: The role of non-economic motivations". Industry and innovation, v. 23, pp. 87-111.

https://doi.org/10.1080/13662716.2015.1126502

Campos-Freire, Franscisco; Rúas-Araújo, José (2016). “Uso de las redes sociales digitales profesionales y científicas: el caso de las 3 universidades gallegas". El profesional de la información, v. 25, n. 3, pp. 431-440.

https://doi.org/10.3145/epi.2016.may.13

Del-Río-Duque, Martha-Lilia (2009). "Un análisis de la fuga de cerebros desde la teoría de redes sociales". Revista sociedad y economía, n. 17, pp. 89-113.

http://www.redalyc.org/pdf/996/99612495005.pdf

Delgado-Morales, Raúl; Melchor, Lorenzo; Oliver, Eduardo (2013). “Atracción y consolidación del talento científico en España". El país, 26 mayo.

https://elpais.com/sociedad/2013/05/26/actualidad/1369588776_232498.html

Deville, Pierre; Wang, Dashun; Sinatra, Roberta; Song, Chaoming; Blondel, Vincent D.; Barabási, Albert-László (2014). "Career on the move: Geography, stratification, and scientific impact". Scientific reports, v. 4, art. 4770.

https://doi.org/10.1038/srep04770

Fangmeng, Tian (2016). "Brain circulation, diaspora and scientific progress: A study of the international migration of Chinese scientists, 1998-2006". Asian and Pacific migration journal, v. 25, n. 3, pp. 296-319.

https://doi.org/10.1177/0117196816656637

Fernández, Lola (2010). "El área de salud copa la fuga de cerebros investigadores". Cinco días, 17 agosto. http://cincodias.com/cincodias/2010/08/17/economia/1282024588_850215.html

Fernández-Magariño, Javier (2005). "Salvador Ordóñez: Captaremos científicos de nivel, sean o no sean españoles". Cinco días, 22 julio.

http://cincodias.com/cincodias/2005/07/22/sentidos/1121999236_850215.html

Franzoni, Chiara; Scellato, Giuseppe; Stephan, Paula (2012). “Foreign-born scientists: Mobility patterns for 16 countries". Nature biotechnology, v. 30, n. 12, pp. 1250-1253.

https://doi.org/10.1038/nbt.2449 
Gaillard, Anne-Marie; Gaillard, Jacques (2015). "Return migration of highly skilled scientists and engineers to Morocco: Return or circulation?". Science, technology and society, v. 20, n. 3, pp. 414-434.

https://doi.org/10.1177/0971721815597157

García-Romero, Antonio (2012). "Influencia de la carrera investigadora en la productividad e impacto de los investigadores españoles. El papel de la ventaja acumulativa”. Revista española de documentación científica, v. 35, n. 1, pp. 38-60. https://doi.org/10.3989/redc.2012.1.762

Gargiulo, Floriana; Carletti, Timoteo (2014). "Driving forces of researchers mobility". Scientific reports, v. 4, art. 4860. https://doi.org/10.1038/srep04860

Gibson, John; McKenzie, David (2014). "Scientific mobility and knowledge networks in high emigration countries: Evidence from the Pacific". Research policy, v. 43, n. 9, pp. 1486-1495.

https://doi.org/10.1016/j.respol.2014.04.005

González-Díaz, Cristina; Iglesias-García, Mar; Codina, Lluís (2015). “Presencia de las universidades españolas en las redes sociales digitales científicas: caso de los estudios de Comunicación". El profesional de la información, v. 24, n. 5, pp. 640-647.

https://doi.org/10.3145/epi.2015.sep.12

Grabowicz, Przemyslaw A.; Ramasco, José J.; Moro, Esteban; Pujol, Josep M.; Eguiluz, Víctor M. (2012). "Social features of online networks: The strength of intermediary ties in online social media". PLoS one, v. 7, n. 1.

https://doi.org/10.1371/journal.pone.0029358

Jacob, Merle; Meek, V. Lynn (2013). "Scientific mobility and international research networks: Trends and policy tools for promoting research excellence and capacity building". Studies in higher education, v. 38, n. 3, pp. 331-344. https://doi.org/10.1080/03075079.2013.773789

Jurgenson, Nathan (2012). "When atoms meet bits: Social media, the mobile web and augmented revolution". Future internet, v. 4, n. 1, pp. 83-91. https://doi.org/10.3390/fi4010083

Kalton, Graham (1983). Introduction to survey sampling. California: SAGE Publications. ISBN: 0803921268

Kato, Maki; Ando, Asao (2017). "National ties of international scientific collaboration and researcher mobility found in Nature and Science". Scientometrics, v. 110, n. 2, pp. 673-694.

https://doi.org/10.1007/s11192-016-2183-z

Lafuente Ibáñez, Carmen; Marín-Egoscozábal, Ainhoa (2008). “Metodologías de la investigación en las ciencias sociales: Fases, fuentes y selección de técnicas". Revista Escuela de Administración de Negocios, n. 64, pp. 5-18. http://decubacubawww.redalyc.org/articulo.oa?id=20612981002

Manca, Stefania; Ranieri, Maria (2017). "Networked scholarship and motivations for social media use in scholarly communication". International review of research in open and distributed learning, v. 18, n. 2, pp. 123-138. https://doi.org/10.19173/irrodl.v18i2.2859

Mas-Bleda, Amalia; Aguillo, Isidro F. (2013). "Can a personal website be useful as an information source to assess individual scientists?: The case of European highly cited researchers". Scientometrics, v. 96, n. 1, pp. 51-67. https://doi.org/10.1007/s11192-013-0952-5

McEvily, Bill; Zaheer, Akbar (1999). "Bridging ties: A source of heterogeneity in competitive capabilities". Strategic management journal, v. 20, n. 12, pp. 1133-1156.

https://doi.org/10.1002/(SICI)1097-0266(199912)20:12<1133::AID-SMJ74>3.0.CO;2-7

Merton, Robert K. (1968). "The Matthew effect in Science". Science, v. 159, n. 3810, pp. 56-63. https://doi.org/10.1126/science.159.3810.56

Merton, Robert K. (1988). "The Matthew effect in science II. Cumulative advantage and the symbolism of intellectual property". ISIS, v. 79, n. 4, pp. 606-623.

https://www.jstor.org/stable/234750

Mihi-Ramírez, Antonio; García-Rodríguez, Yolanda; Cuenca-García, Eduardo (2016). "Innovation and international high skilled migration". Engineering economics, v. 27, n. 4, pp. 452-461.

https://doi.org/10.5755/j01.ee.27.4.14396

Montobbio, Fabio; Sterzi, Valerio (2013). "The globalization of technology in emerging markets: A gravity model on the determinants of international patent collaborations". World development, v. 44, pp. 281-299.

https://doi.org/10.1016/j.worlddev.2012.11.017 
Murthy, Dhiraj; Lewis, Jeremiah P. (2015). "Social media, collaboration, and scientific organizations". American behavioral scientist, v. 59, n. 1, pp. 149-171.

https://doi.org/10.1177/0002764214540504

Palacios-Callender, Miriam; Roberts, Stephen A. (2018). "Scientific collaboration of Cuban researchers working in Europe: Understanding relations between origin and destination countries". Scientometrics, v. 117, n. 2, pp. 745-769.

https://doi.org/10.1007/s11192-018-2888-2

R. E, M. (2003). “Más de 2.000 investigadores se apuntan a un censo". El país, 4 abril.

http://elpais.com/diario/2003/04/04/sociedad/1049407205_850215.html

Raicex (2018). iNace Raicexi Red de Asociaciones de Investigadores y Científicos Españoles en el Exterior.

https://raicex.wordpress.com/jornada-de-presentacion-de-raicex

Rodrigues, Marcio L.; Nimrichter, Leonardo; Cordero, Radames J. B. (2016). "The benefits of scientific mobility and international collaboration". FEMS microbiology letters, v. 363, n. 21.

https://doi.org/10.1093/femsle/fnw247

Rodríguez-Bravo, Blanca; Nicholas, David (2019). “Reputación y comunicación científica: investigadores españoles en el inicio de su carrera”. El profesional de la información, v. 28, n. 2.

https://doi.org//10.3145/epi.2019.mar.03

Rodríguez-Fernández, María-Magdalena; Sánchez-Amboage, Eva; Martínez-Fernández, Valentín-Alejandro (2018). "Utilización, conocimiento y valoración de redes sociales digitales científicas en las universidades gallegas". El profesional de la información, v. 27, n. 5, pp. 1097-1107.

https://doi.org/10.3145/epi.2018.sep.13

Segado-Boj, Francisco; Chaparro-Domínguez, María-Ángeles; Castillo-Rodríguez, Cristina (2015). “Use of Twitter among Spanish communication-area faculty: Research, teaching and visibility". First Monday, v. 20, n. 6.

https://doi.org/10.5210/fm.v20i6.5602

Sugimoto, Cassidy R.; Robinson-García, Nicolás; Murray, Dakota S.; Yegros-Yegros, Alfredo; Costas, Rodrigo; Larivière, Vincent (2017). "Scientists have most impact when they're free to move". Nature, v. 550, n. 7674, pp. 29-31.

https://doi.org/10.1038/550029a

Walsh, John P.; Kucker, Stephanie; Maloney, Nancy G.; Gabbay, Shaul (2000). “Connecting minds: Computer-mediated communication and scientific work". Journal of the American Society for Information Science, v. 51, n. 14, pp. 1295-1305. https://doi.org/10.1002/1097-4571(2000)9999:9999<::AID-ASI1046>3.0.CO;2-W

Ward, Judit; Bejarano, William; Dudás, Anikó (2015). "Scholarly social media profiles and libraries: A review". Liber quaterly, v. 24, n. 4, pp. 174-204.

https://doi.org/10.18352/lq.9958

Yazdizadeh, Bahareh; Majdzadeh, Reza; Alami, Ali; Amrolalaei, Sima (2014). "How can we establish more successful knowledge networks in developing countries? Lessons learnt from knowledge networks in Iran". Health research policy and systems, v. 12, n. 63.

https://doi.org/10.1186/1478-4505-12-63

Zdravkovic, Marta; Chiwona-Karltun, Linley; Zink, Eren (2016). “Experiences and perceptions of South-South and North-South scientific collaboration of mathematicians, physicists and chemists from five Southern African universities". Scientometrics, v. 108, n. 2, pp. 717-743.

https://doi.org/10.1007/s11192-016-1989-z

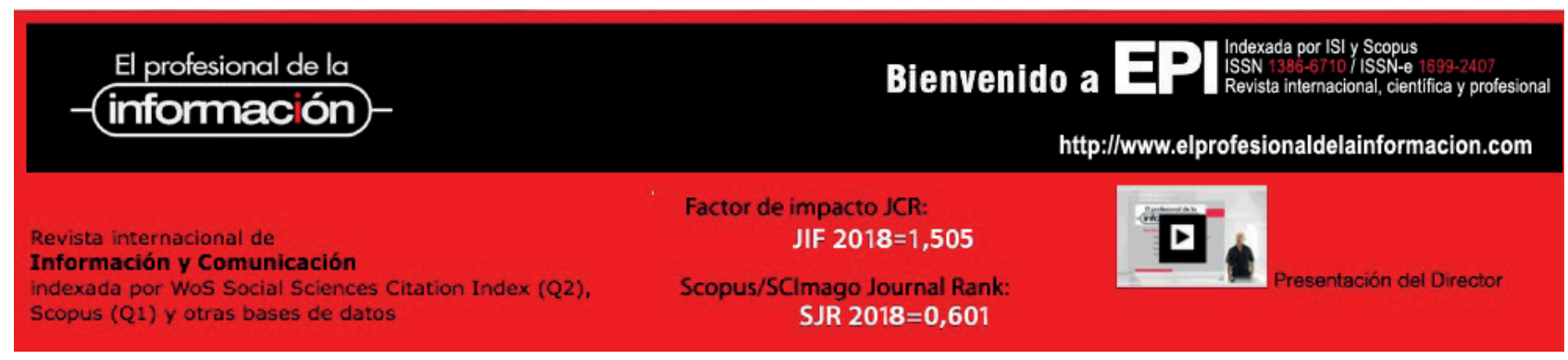

